\title{
In Search of the State: A Ethnography of Public Service Provision in Urban Niger
}

Thèse de Doctorat (PhD), Uppsala University (Suède), 2011

\section{Gabriella Körling}

\section{OpenEdition \\ Journals}

Electronic version

URL: http://journals.openedition.org/anthropodev/330

DOI: 10.4000/anthropodev.330

ISSN: 2553-1719

Publisher

APAD - Association pour l'anthropologie du changement social et du développement

Printed version

Date of publication: 1 September 2014

Number of pages: 199

ISBN: 9791093476018

ISSN: 2276-2019

Electronic reference

Gabriella Körling, «In Search of the State: A Ethnography of Public Service Provision in Urban Niger », Anthropologie \& développement [Online], 40-41 | 2014, Online since 01 September 2016, connection on 24 September 2020. URL : http://journals.openedition.org/anthropodev/330 ; DOI : https://doi.org/ 10.4000/anthropodev.330

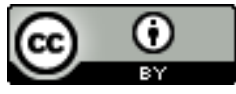

La revue Anthropologie \& développement est mise à disposition selon les termes de la Licence Creative Commons Attribution 4.0 International. 


\title{
In Search of the State: An Ethnography of Public Service Provision in Urban Niger
}

\author{
Gabriella Körling ${ }^{1}$ \\ Thèse de Doctorat (PhD), Uppsala University (Suède), 2011
}

\section{Résumé}

This study explores public health and education provision in Niamey, the capital of Niger, by merging the ethnographic study of public services with an anthropological analysis of the state and of local politics. Based on anthropological fieldwork carried out in a group of neighbourhoods in the periphery of Niamey, the study highlights the political dimensions of public service provision in a local arena where international development interventions and national plans meet local realities and where a wide range of actors and institutions, discourses, meanings, and practices are mobilized in the offering of and the regulation of access to public services. It focuses on the political, economic, and socio-cultural aspects of public service provision, too often hidden behind contemporary buzzwords of development such as community participation and decentralization that dominate global debates about education and healthcare in developing countries. The study brings forth the strategies of urban residents in dealing with daily challenges in the consolidation of service provision and in education and health-seeking trajectories. It shows that access to a satisfactory treatment of illness or a successful school career is premised on the ability to navigate on the medical and education markets, which are made up of a plurality of providers and of official and unofficial costs and transactions. Further, these public services engage different actors such as community committees, traditional chiefs, local associations, the municipality and elected municipal councillors, emergent leaders, NGOs, and international development aid. The study demonstrates that despite the uncertainty of state support in health and education provision and a widespread dissatisfaction with these public services, the image of the state as service provider is reproduced on a day-by-day basis through local efforts at securing public services.

${ }^{1}$ E-mail : gabriella.korling@antro.uu.se

Published in Uppsala Studies in Cultural Anthropology 51 by Acta Universitatis Upsaliensis, Uppsala University 2011. 